\title{
INVESTMENTS IN AGRICULTURAL HOLDINGS IN THE EU (10) COUNTRIES BY THE PRISM OF THE MICHAL KALECKI'S BUSINESS CYCLE THEORY
}

\author{
Piotr Kulyk ${ }^{1}$, PhD with habilitation associate professor; \\ Aleksander Grzelak ${ }^{2}$, PhD with habilitation associate professor \\ ${ }^{1}$ University of Zielona Gora, ${ }^{2}$ Poznan University of Economics and Business
}

\begin{abstract}
The main objective of the article is to evaluate investment processes in agriculture in the EU countries (10) in 2004-2013 from the perspective of M. Kalecki's investments business cycle theory. Panel regression was used for model estimation. One has stated that investments in agricultural holdings can be considered from the perspective of the investment theory of the business cycle of $M$. Kalecki in the case of a group of the EU countries (10). This means that increasing investments in one year leads to an increase in production resources in the next period, which reduces the demand for investment. It was noted that the demand effect of investment is relatively stronger than supply one. This phenomenon results, among others, from the fact that there are investments in agriculture that do not translate into production effects or the creation of further ones (e.g. related to ensuring the well-being of the environment under cross-compliance). After 2020, it would be advisable to include to a greater extent, in the support instruments of the CAP the creation of public goods, which weaken the effect of the supply effect of the investment.
\end{abstract}

Key words: agricultural holding, investments, the Michal Kalecki's business cycle theory.

JEL code: E11, E32, Q12

\section{Introduction}

The economic situation of agricultural holdings depends to a large extent on investment processes. Their scope, as well as character, determines the directions of development of this sector. Covering of agriculture with the instruments of the Common Agriculture Policy (CAP) of the new member states gave a significant impulse to the development processes of agricultural holdings due to the increase in financial support. Assuming that investments in agriculture initiate growth processes in sectors generating investment goods for this sector through the investment multiplier mechanism, the issue of their evaluation essentially goes beyond agriculture.

The investments in agriculture have been dynamised after integration with the EU, but this mainly concerned investments in the mechanization (purchase of tractors, means of transport), with low activity in the area of construction investments (Grzelak A., 2014). It resulted from the current needs of farmers as well as the direction of using investment support (mainly the purchase of farm equipment with machinery, equipment and tools for agricultural production). The dominance of this type of investment was associated with a less risky and easier way to obtain and account for investment funds from the EU funds for the purchase of machinery and equipment (Poczta W., Czubak W., 2007). These phenomena also had a relationship in Poland, as well as in other countries of the Central and Eastern Europe, with a downward trend in pig farming and resignation from animal production in smaller farms. Agriculture in the EU countries, especially since the budget perspective 2007-2013, has increased the importance of non-productive investments due to the fulfilment of cross-compliance and, in the next financial perspective, by increasing the role of environmental considerations (e.g. biodiversity, bioenergy). As a result, the increase in the value of fixed assets is less pro-productive and income-generating. On the other hand, therefore, farms are more pro-environmental, creating public goods (Smedzik-Ambrozy K., Guth M., 2016).

The research in the field of investment in agriculture has a rich tradition in the literature and concerns on many issues related to this. Among other things, it is indicated that the costs of raising capital are one of the most important factors determining the investment possibilities of 
agricultural holdings (Barry et al., 2000). In turn Swinnen and Gow (1999) emphasize that, the use of external sources of finance is facilitated on larger farms. This favours in the development of these farms as well as the modernization of the fixed assets, thus allowing the use of leverage effects. At the same time, larger farms tend to have a stronger tendency to risk hence debt and investment activity are relatively higher there. The experience of French and British farms (Benjamin C., Filmister E., 2002) shows that investments are sensitive to changes in cash flows as well as to the functioning of capital markets, including the level of credit collateral. In other studies (Winters et al. 2009), attention was paid to the relationship of investment and capital, indicating that they depend on agricultural support instruments. Their research, groups of 15 developing countries from different continents of the world, shows that the value of assets and accumulation in agricultural holdings is the result of state intervention policy. While in research of agriculture in the countries of the Central and Eastern Europe Christensen, Lacroix (1997) critically referred to support for investment in loan interventionism. This is especially about a redistribution of income for more economically strong producers. In turn, (Wu et al., 2014) draw attention to demographic issues, indicating that older farm owners have lower risk acceptance and therefore are more conservative in undertaking investment projects.

The main aim of the article is to evaluate investment processes in agriculture in the EU countries (10) in 2004-2013 from the perspective of M. Kalecki's investments business cycle theory. This allowed for analysis in the context of both the demand and supply side of the investment effect in agricultural holdings. It is also about recognizing whether the investment sphere of farms is so strong that it forms the basis for repeated cyclical fluctuations. So the main task of the research is to estimate the demand and supply effect of the investment in agricultural holdings using the Kalecki's model. The article uses the results of agricultural holdings that keep accounts in line with the principles of the EU FADN. The point is that this data is microeconomic and refers to the average agricultural holding farm in the field of observation of the FADN system. Thus, they are a representative of the economic and production situation of thousands of farms in a given country, which produce at least $90 \%$ of the value of standard agricultural output $(\mathrm{SO})^{1}$. The spatial range of the research concerns the agricultural holdings from the EU countries (10), so those countries that are new members since at least 2004. This enabled the creation of a group of homogeneous units (countries) as to the duration of EU CAP instruments. In order to limit the influence of fluctuations of the tested parameters on the results of the estimated model, time series were adjusted using a 3 periods moving average.

Panel regression was used for model estimation, which is a type of two-level modelling (space, time) with fixed coefficients and random 'within' and/or 'between' effects (Wooldridge J., 2002). This method uses variables observed in at least two dimensions, e.g. temporal-spatial. Hence, the behaviour of each observed unit is influenced by individual factors, resulting solely from its peculiarities, as well as by other factors, affecting the activities of all objects in the same way.

The diagnostic test of the Breusch-Pagan and Hausman panel was chosen for the method selection (Hausman J., Taylor W., 1981). Choosing a model with random effects as the most appropriate means that individual effects are fixed over time but cannot be attributed to individual countries. It can therefore be assumed that agricultural holdings in the EU countries undergo similar external pressures that cannot be unequivocally attributed to a specific location (country).

${ }^{1}$ Standard output (SO) is the average of 5 years of production value of a specific agricultural activity (plant or animal) from 1 ha or from 1 animal per 1 year, in the region's average production conditions. . 
This is due to two reasons. The first refers to the very specifics of agricultural holdings as a business entities and their peculiar resources, including land in particular. The second is related to subjecting these entities to the impact of the EU common agricultural policy, which significantly influences the obtained results (Kulyk P., 2013). The role of this first aspect is determined by the fact that regardless of the situation of the holdings, including the length of coverage of the CAP, we obtained the effect of not linking with the given location. Such an effect should be expected when we take into account the impact of this policy, which in various respects (primarily time) shaped the conditioning of agricultural holdings in the EU Member States. The article uses a model with random effects.

\section{Selected elements of the business cycle theory by Michal Kalecki}

The theory of the business cycle of M. Kalecki (1933) was formulated as a function of investment (1)

$$
I_{t+1}=a S_{t}+b \Delta I_{t}-m \Delta K_{t}
$$

where:

$I_{t+1}$-next year investments $(\mathrm{t}+1)$

$S_{t}$--entrepreneurship funds available for accumulation (depreciation, undivided corporate profits, savings)

$\Delta I_{t}$-change in investment expenditure

$\Delta K_{t}$-change in production capacity in the national economy due to the difference between gross investment and loss of production resources withdrawn from production $\left(\mathrm{U}^{1}\right)$, thus $\Delta K_{t}=\mathrm{I}_{\mathrm{t}}-\mathrm{U}_{\mathrm{t}}$.

$a, b, m$-parameters of the linear function

t-years in the business cycle

This theory is based on the contradiction between the demand and the supply context of investment. The demand dimension is that investments (I) create increased demand for investment products. These investments in subsequent periods are embodied in capital resources, thereby increasing production capacity (supply dimension). In this way, 'today's' investments inhibit 'tomorrow' due to increasing production capacity. On the other hand, when the level of investments is lower than the average amount of capital consumption, capital stock decreases $\left(\Delta \mathrm{K}_{\mathrm{t}}\right.$ $<0$ ), which in turn stimulates investment demand due to the need to achieve at least simple reproduction of assets. Hence, the mechanism of cyclical fluctuations in the economy follows, according to this theory, the interaction between investments and their differentiating nature. While the investment alternatives as well as the own funds available for the accumulation affect positively the further investments of enterprises, the changes of the capital stock - negatively (equation 1). Many investment projects cannot be realized simply because they require a significant increase in external resources (Kalecki M., 1935). In the case of agriculture, this applies especially to smaller farms.

In this paper, the model was implemented for changes occurring in the farms and explanation of investment activity. Relative repeatability of phenomena in agriculture may indicate the existence of a permanent mechanism for the occurrence of repetitive changes. The article identifies the

${ }^{1}$ It is assumed in this model that $\mathrm{U}$ is shaped at the same level in all phases of the cycle. 
antagonistic and contradictory nature of the market mechanism as one of the cause of cyclical fluctuations of investments. Crisis phenomena will only appear when increased production hits the demand barrier, which results in a decrease in profitability of investments, shrinking investment processes.

Contemporary views of Kalecki's model refer to the issues related to the capital structure used to finance investments, including the reduction of the role of internal finances in the real sector of the economy, influencing its cyclical fluctuations (Hein E., van Treeck T., 2010). In the case of agriculture, this concerns budget transfers and credits, often sustained by the first source. One of the important factors is also the occurrence of rising costs of adaptation of capacity changes to external requirements (Asada T., 2006; Schoder C., 2011). Moreover, in the Kalecki 's model, the assumption is made that investments bring about productive effects by increasing the production apparatus. In the meantime, it is possible to find situations where investments are not of a production nature. In the case of agriculture, it may concern investments related to the provision of higher quality standards, environmental regulations in agricultural production, animal welfare or ergonomics. Also there may be doubts about the translation of this macroeconomic theory to microeconomic, or more meso-economic level. If we assume that the aggregated data reflects the behaviour of economic operators that are the resultant of individual units or sectors, then this should not be an obstacle. All the more so, it is possible to formulate conclusions about the peculiarities of investment behaviour, in this case - farms. In the literature of the subject, such references can be found, albeit for other sectors. For example, Fazzari and Mott (1987) used this model to study the determinants of industrial investment in the USA. Thus, it is possible to use this model for sectoral analysis. Irrespective of the imperfections indicated the Kalecki's model is thought to be a useful tool for country analysis (Blecker R., 2002). In the light of the above arguments, we believe that M. Kalecki's theory, despite the passage of many years since its inception, is still valid, which results from its universalism. This is a mechanism for the emergence of repeated investment fluctuations as a consequence of the contradiction between the demand and supply side of the investment.

In our case, the Kalecki's model takes the following form (2) after modifications:

$$
I_{t+1}=\beta_{0}+\beta_{1} S_{t}+\beta_{2} \Delta I_{t}-\beta_{3} \Delta K_{t}
$$

where:

$\mathrm{I}_{\mathrm{t}+1^{-}}$investments less the purchase value of land (based on the land area balance multiplied by the value of land in the current year)

$\mathrm{S}_{\mathrm{t}}$-the economic surplus obtained after the payment of the employment factor in the previous year (farm income increased by depreciation and reduced by calculated costs of self-employment)

$\Delta \mathrm{I}_{\mathrm{t}}$ - difference in investment level (excluding investment in land) between the current year and the previous one

$\Delta \mathrm{K}_{\mathrm{t}}$-difference in fixed assets value (excluding land) $=\mathrm{I}_{\mathrm{t}}-\mathrm{U}_{\mathrm{t}}$ ( $\mathrm{I}_{\mathrm{t}}$ excluding land)

The modification of the model (mainly related to the exclusion of land values from investments and fixed assets) takes account of the specificity of agricultural production and, in particular, the economic account of farms where we are dealing with a high level of self-employment. The exclusion of the land factor is due to its peculiarity. The point is that its value is also linked to the amount of subsidies received in this case from the EU's common agricultural policy, to the development of other segments of the economy, including rural urbanization. Moreover, the value 
of land was often speculative, as evidenced by the significant increase in its value in some countries (e.g. in Poland), (Krupowicz et al., 2015). Significantly exceeding both the level of inflation and the increase in its productivity. There are also disruptions related to capitalization of area payments in the price of agricultural land (Ciaian P., Kancs D., 2012; Van Herck K., Vranken L., 2013).

The variable S, i.e. entrepreneurs' funds available for the purpose of accumulation (equations 1 and 2), is estimated as the difference between the farm's surplus (sum of agricultural income and depreciation) and the payment for farmer's own family work. On the other hand, the self-employed rate was estimated on the basis of the hourly workload and the wage rates employed on the farm. This approach makes it possible to determine the potential surplus subtracting the opportunity cost of own family labour from farm income) at the level of the farm that is available for use for accumulation, i.e. the purchase of fixed assets. In order to limit the influence of fluctuations of the tested parameters on the results of the estimated model, time series were adjusted using a 3 periods moving average. Verification of models accepted the compatibility of the analysed variables with the theory of economics. It is worth emphasizing that the main idea of the study is to verify the analysed theory and not to use it for prognostic purposes. We used the Gretl program to estimate the models.

\section{Research results and discussion}

The conducted research. through the panel analysis, showed that the direction of impact of the independent variables adopted for estimation (Tab.1) is compatible with the theoretical assumptions included in the Kalecki's model. Model with random effects for all groups of farms was applied to estimate the parameters of the model for 10 newly integrated countries in 2004. This choice was dictated on the one hand by the low value of the Breusch-Pagan test, which indicated the use of the panel method and on the other hand, the value of the Hausman test exceeded the assumed level of 0.05 .

Random effects estimation (GLS), with 90 observations, included 10 crosssectional units, time series for dependent variable $(Y)$ : $I_{t+1}$ for farms

\begin{tabular}{|c|c|c|c|c|c|}
\hline No & Variables & coefficient & Standard error & t-Student & Value p \\
\hline 1. & const & 6418.29 & 1868.21 & 3.436 & $0.0006 * * *$ \\
\hline 2. & St & 0.6835 & 0.0694 & 9.853 & $6.66 \mathrm{e}-023 * * *$ \\
\hline 3. & $\Delta \mathrm{It}$ & 0.7836 & 0.4120 & 1.902 & $0.0572 *$ \\
\hline 4. & $\Delta \mathrm{Ft}$ & -0.1266 & 0.0396 & -3.195 & $0.0014 * * *$ \\
\hline \multicolumn{2}{|c|}{ 'Between' variance } & $1.003 e+008$ & \multicolumn{3}{|c|}{ 'Within' variance $2.07 e+008$} \\
\hline \multicolumn{6}{|c|}{$\begin{array}{l}\text { Breusch-Pagan test Null hypothesis: Error variance in unit }=0 \\
\text { Asymptotic test statistics: Chi-square }(1)=0.0190998 \text { with value } p=0.0662\end{array}$} \\
\hline \multicolumn{6}{|c|}{$\begin{array}{l}\text { Hausman test Null hypothesis: UMNK (GLS) estimator is consistent } \\
\text { Asymptotic test statistics: Chi-square }(3)=5.67379 \text { with value } p=0.1286\end{array}$} \\
\hline
\end{tabular}

$*, * *, * * *$ statistically significant at $10 \% .5 \%$ and $1 \%$ levels respectively

Source: authors' study based on FADN data

Using a model with random effects means that individual effects are fixed over time but can ' $t$ be attributed to individual countries. It also indicates the homogeneity of conditions in this group of countries. This could be related to the increase in investment activity in agriculture in the new Member tates after integration with the EU (Zidkova et al., 2011; Grzelak A., 2013) as a consequence of increased support for this sector. The fact of determining (in the sense of the 
quality of the model, see table 1) of the universal model seems particularly important. It covers all examined EU countries (10) despite of the existing disproportions between the considered countries, including in particular structural differences (average size of the farm or the importance of labour and capital). The significance of random factors demonstrated in the model also results from the existence of strong support from subsidies from the common agricultural policy (CAP) of the EU. This model has not been taken into account because the scope using subsidies for investment purposes depends on the marginal propensity to invest (and this from a phase of the business cycle) as well as the type of support. Also, support affects both investment financing and asset growth (capitalization), as well as investment costs (an increase of land prices (Dwyer J., 2012). Hence the direction of relationships is uneven and difficult to capture in the model. The 'between 'variance value is less compare to 'within', suggesting that the models better explain differences within countries than between countries. This is compatible with the assumption made for random effects. The model has a high level of significance for the $S$ and $\Delta F$ variables, which is also indicated by the high values of t-Student (Table 1). The demand effect of investments, in agricultural holdings in the studied countries expressed through the impact of the variable $\Delta \mathrm{I}_{\mathrm{t}}$, was stronger than the supply effect $(\Delta \mathrm{Ft})$. This is visible at the coefficients $(0.78$ and 0.13$)$ (Table 1$)$. This may result from the relative dispersion of bargaining power of farms and hence limited competitive impact. It was observed that any increase in investments minus the value of land purchase increased investments (decreased by the value of land purchase). On the other hand, the change in the value of fixed assets (excluding land) had a negative impact on the level of investments in the following year. At the same time, this variable assumed the highest value of the coefficient (0.78) (similarly to the independent variable S). It was one of the mechanisms determining investment in farms in this studied group of countries. These results may indicate the inertia of investment processes. This inertia can also be associated with the gradual activation of the payments in the subsequent programs of the CAP. On the other hand, investment processes in next periods affect the value of the obtained economic surplus, which in the case of unfavourable economic conditions may be reduced as a result of this process. The point is that expenditures are incurred, but increased production capacities with a fall in prices of agricultural products deteriorate the result of the all agricultural sector. This is due to the low elasticity of food demand. A similar dependence can be seen in the growth of the economic surplus of farms, which translates into an increase in investments in the current year. In this case, it is the expected change and shows, that the improvement of economic conditions favours investment processes related to agricultural production (there is no reallocation of capital for other uses).

\section{Conclusions}

1) The analysis carried out on the panel data confirm that investments in agricultural holdings can be considered from the perspective of investment theory of the business cycle of M. Kalecki in the case of a group of the EU countries (10). This means that increasing investments in one year leads to an increase in production resources in the next, which reduces the demand for investment. As a consequence, this may lead to the creation of a cyclic variation mechanism. However, it should be remembered that this is only one of the developmental mechanisms of farms besides those connected with the impact of the business outlook situation.

2) It was noted that the demand effect of investment is relatively stronger than supply. This may be related to the fact that agriculture through the support system (CAP), as well as the peculiarities 
of this sector (production dispersion, relative atomization of agricultural producers, seasonality of production, a creation of public goods) has weakened internal market stimuli. Also, this phenomenon results from the fact that there are investments in agriculture that do not translate into production effects or the creation of further ones (e.g. related to ensuring the well-being of the environment under cross-compliance).

3) The research results, obtained in the work, may also be a premise for the directions of the evolution of the EU CAP. After 2020 it would be advisable to include to a greater extent, in the support instruments of the CAP the creation of public goods, which weaken the effect of the supply effect of the investment. At a next stage, it would be necessary to verify the completed studies at the level of regions, which would increase the number of observations as well as the level of significance.

\section{Bibliography}

1. Asada, T. (2006). Stabilization Policy in a Keynes-Goodwin Model with Debt Accumulation. Structural Change and Economic Dynamics, Vol. 17, pp 466-485.

2. Barry, P., Bierlen,, R., Sotomayor, N. (2000). Financial Structure of Farm Businesses Under Imperfecta Capital Markets. American Journal of Agricultural Economics, No 82 (4), pp. 920-933.

3. Benjamin, C., Phimister, E. (2002). Does Capital Market Structure Affect Farm Investment ? A Comparison Using French and British Farm-level Panel Data. American Journal of Agricultural Economics, Vol 84. No 4, pp. 1115-1129.

4. Blecker, R. (2002). Distribution. Demand and Growth in Neo-Kaleckian Macro-models. In M. Setterfield. (Eds.), The Economics of Demand-led Growth: Challenging the Suply-Side Vision of the Long Run. Edward Elgar Publishing, pp. 129-152.

5. Christensen, G.. Lacroix, R. (1997). Competitiveness and Employment. A Framework for Rural Development in Poland. World Bank Discussion paper. 383. Washington DC.

6. Ciaian, P., Kancs, D. (2012). The Capitalization of Area Payments into Farmland Rents: Micro Evidence from the new EU Member States. Canadian Journal of Agricultural Economics. Special Issue, Vol. 60, pp. 517540.

7. Dwyer, J. (2012). The Relativistic Feedback Discharge Model of Terrestrial Gamma Ray Flashes. Journal of Geophysical Research, No 117, Issue A2, pp. 1-25.

8. Fazzari, S., Mott, T. (1987). The Investment Theories of Kalecki and Keynes: an Empirical Study of Firm Data. 1970-1982. Journal of Post Keynesian Economics, Vol IX, No. 2, pp. 171-187.

9. Grzelak, A. (2014). Ocena Procesow Reprodukcji Majatku Gospodarstw Rolnych Prowadzacych Rachunkowosc Rolna (FADN) (Evaluation of the Reproduction Processes of the Fixed Assets of Farms Engaged in Agricultural Accountancy (FADN). Zagadnienie Ekonomiki Rolnej, No 2, pp. 45-64.

10. Grzelak, A. (2013). The Investment Activity of Agriculture in Poland Following the Integration with the EU. Scientific Works. Agricultural University Plovdiv, Vol.LVII, pp. 55-62.

11. Hausman, J., Taylor, W. (1981). Panel Data and Unobservable Individual Effects. Econometrica, Vol. 49.

12. Hein, E., van Treeck, T. (2010). 'Financialisation` in Post-Keynesian Models of Distribution and Growth: a Systematic Review. In M. Setterfield. (Eds.), Handbook of Alternative Theories of Economic Growth. Edward Elgar Publishing, pp. 277-292.

13. Kalecki, M. (1933). Proba Teorii Koniunktury (The Attempt of Theory of Business Outlook). PWE, Warszawa.

14. Kalecki, M. (1935). A Macrodynamic Theory of Business Cycle. Econometrica, Vol. 3, No.3.

15. Kulyk, P. (2013). Finansowe Wsparcie Rolnictwa w Krajach o Roznym Poziomie Rozwoju Gospodarczego (Financial Support for Agriculture in Countries with Different Levels of Economic Development). Wyd. Uniwersytet Ekonomiczny w Poznaniu, Poznan.

16. Krupowicz, W., Bielska, A., Budzynski, T. (2015). The Effects of Defective Spatial Structure on the Agricultural Property Market. Folia Oeconomica Stetinensia, 15(1), p. 174.

17. Poczta, W., Czubak, W. (2007). Bariery Pozyskiwania Srodkow UE na Cele Inwestycyjne przez Gospodarstwa Rolne (The Barriers of Obtaining the EU Funds for Investment Purposes by Agricultural Holdings. In Identyfikacja i Ocena Barier Administracyjnych Realizacji Programow Rozwoju Obszarow Wiejskich (Identification and Assessment of Administrative Barriers to the Implementation of Rural Development Programs). IERiGZ - PIB Program Wieloletni 2005-2009, No 66.

18. Schoder, C. (2011). Kaleckian vs. Marxian Specifications of the Investment Function:SomeEmpiricalEvidence for the USA. MPRA Paper No. 29584: 1-24. Available at https://mpra.ub.uni-muenchen.de/29584/2/MPRA_paper_29584.pdf.

19. Smedzik-Ambrozy, K., Guth, M. (2016). Public Goods in the Common Agricultural Policy of European Union Countries. In B. Czyzewski (Eds.), Political Rents of European Farmers in The Sustainable Development Paradigm. Warszawa. PWN, pp. 131-140. 
20.Swinnen J., Gow, H. (1999). Agricultural Credit Problems and Policies During the Transition to a Market Economy in Central and Eastern Europe. Food Policy, Vol. 24.

21. Winters, P., Benjamin, D., Gero, C., Covarrubias, K., Quinones, E., Zezza, A., Azzarri, C., Stamoulis, K. (2009). Assets. Activities and Rural Income Generation: Evidence from a Multicountry Analysis. World Development. Vol 37, No 9, pp. 435-1452.

22. Wooldridge, J. (2002). Econometric Analysis of Cross Section and Panel Data. London. MIT press.

23. Wu, F., Guan, Z., Myers, R. (2014). Farm Capital Structure Choice: Theory and an Empirical Test. Agricultural Finance Review, Vol. 74, Iss 1, pp. 115 - 132.

24. Zidkova D., Rezbova H., Rosochatecka E. (2011). Analysis of Development of Investments in the Agricultural Sector of the Czech Republic. Agris on-line Papers in Economics and Informatics, Vol. 3, Iss 1 , pp. 33-42. 